Tropical Journal of Pharmaceutical Research February 2019; 18 (2): 391-395

ISSN: $1596-5996$ (print); 1596-9827 (electronic)

(C) Pharmacotherapy Group, Faculty of Pharmacy, University of Benin, Benin City, 300001 Nigeria.

\title{
Effect of three kinds of anaesthetic drugs on postoperative recovery, regulatory $T$ cells and $T$ lymphoid cells in elderly patients
}

\author{
Wang Feng-Juan', Yao Yu ${ }^{1 *}$, Ye Hua ${ }^{2}$, Wang Jin-Zhuo ${ }^{3}$, Wu Zhen-Zhong ${ }^{4}$ \\ ${ }^{1}$ Department of Anaesthesiology, ${ }^{2}$ Operating Room, Hospital Attached to Changchun University of Chinese Medicine, No. 1478 \\ Gongnong Road, Chaoyang District, Changchun, Jilin 130021, ${ }^{3}$ Department of Anaesthesiology Changchun Obstetrics- \\ Gynaecology Hospital, No. 555 Wuma West Road, Nanguan District, ${ }^{4}$ Department of Anaesthesiology, Jilin Province Qianwei \\ Hospital, No. 1445 Qianjin Street, Changchun, Jilin 130000, China
}

*For correspondence: Email: rb1279@163.com

\begin{abstract}
Purpose: To investigate the effect of three anaesthetic drugs on postoperative recovery, regulatory $T$ cells and $T$ cell subset levels in elderly patients.

Methods: The patients were randomly divided into groups $A, B$ and $C$ (42 patients per group). Group $A$ received intravenous remifentanil, dexamethasone, dexmedetomidine and propofol, followed by continuous intraoperative inhalation of sevoflurane and continuous intravenous pumping of remifentanil. Group $B$ was given intravenous propofol and midazolam, followed by continuous intraoperative inhalation of sevoflurane, while Group C received intravenous etomidate and rocuronium, with continuous intraoperative inhalation of sevoflurane. The preoperative or 24-h postoperative $T$ regulatory cells $\left(C D 4^{+} C D 25^{+}\right)$and $T$ cell subsets $\left(C D 4^{+}\right.$and $\left.C D 8^{+}\right)$were determined for each group.

Results: MMSE scores in the three groups were lower than their pre-operation scores $(p<0.05)$. There were significant reductions in 24-h postoperative serum $C D 4^{+} C D 25^{+}$and $C D 4^{+}$levels, with higher reductions in group $B(p<0.05)$. In contrast, $C D 8+$ increased in all groups, but was lower in group $B$ than in the other two groups $(p<0.05)$.

Conclusion: These findings strongly suggest that propofol, midazolam and sevoflurane have rapid onset of action and recovery, which improves the comfort of patients while decreasing negative impact on the function of the immune system. Furthermore, these anaesthetic agents enhance the recovery of elderly patients.
\end{abstract}

Keywords: Anaesthesia, Cognitive function, Regulatory $T$ cells, $T$ cell subsets

This is an Open Access article that uses a funding model which does not charge readers or their institutions for access and distributed under the terms of the Creative Commons Attribution License (http://creativecommons.org/licenses/by/4.0) and the Budapest Open Access Initiative (http://www.budapestopenaccessinitiative.org/read), which permit unrestricted use, distribution, and reproduction in any medium, provided the original work is properly credited.

Tropical Journal of Pharmaceutical Research is indexed by Science Citation Index (SciSearch), Scopus, International Pharmaceutical Abstract, Chemical Abstracts, Embase, Index Copernicus, EBSCO, African Index Medicus, JournalSeek, Journal Citation Reports/Science Edition, Directory of Open Access Journals (DOAJ), African Journal Online, Bioline International, Open-J-Gate and Pharmacy Abstracts

\section{INTRODUCTION}

More and more elderly patients have need to undergo surgical operations due to enhanced aging of the global population The surgical trauma and narcotic analgesic drugs used during operations cause immunosuppressive effects which increase the patient's health burden and lead to poor recovery after operations [1]. In elderly patients, the immune system does function optimally. Thus, for elderly patients in need of operation, the right anaesthetic drugs are required, not only to make the operation successful but also to reduce the impact of 
adverse effects such as intraoperative and postoperative pain. Therefore, the use of appropriate anaesthesia improves postoperative recovery. The present study investigated effects of three anaesthetic drugs on the prognosis and immune function of elderly patients.

\section{METHODS}

\section{Selection}

The patients $(n=126)$ undergoing general anaesthesia operations in our hospital from August 2015 to October 2017 were enrolled. The patients and their families were fully aware of the study, and they signed informed consent.

\section{Inclusion criteria}

Patients in the following categories were included: (1) patients in ASA grades II - III; (2) patients without visual impairment or hearing impairment; (3) patients free from neurological or mental illness, (4) patients without severe coagulopathy.

\section{Exclusion criteria}

Patients within the following categories were excluded from the study: (1) diabetic patients without controlled blood glucose; (2) patients with severe liver or kidney disease, and (3) patients who were on other analgesic drugs before the operation. This research was approved by the Ethical Committee of Hospital Attached to Changchun University of Chinese Medicine (approval no. 20180399), and it was carried out according to the guidelines of Declaration of Helsinki promulgated in 1964, as amended in 1996 [3].

\section{Anaesthesia application}

Venous access was opened in the patient, and blood pressure, respiration and heart rate were monitored. Urinary catheter was used on the patients in the operating room. The anaesthesia induction in group $A$ involved intravenous injection of $1.5 \mu \mathrm{g} / \mathrm{kg}$ remifentanil (Yichang Renfu Pharmaceutical Co., Ltd, 20150202), 3 mg/kg propofol (Xi'an Libang Pharmaceutical Co., Ltd, Zhuozi H20010368) and $0.5 \mu \mathrm{\mu g} / \mathrm{kg}$ dexmedetomidine (Shanghai Xuxin Chemical Technology Co., Ltd., 20150628), with continuous inhalation of $3.0 \%$ sevoflurane (Shanghai Hengrui Pharmaceutical Co., Ltd, Guoyaozi H20070172) and continuous intravenous pumping of fentanyl (0.15 $\mu \mathrm{g} / \mathrm{kg} / \mathrm{min}$ ). In group B, anaesthesia was induced with intravenous injection of $1.5 \mathrm{mg} / \mathrm{kg}$ propofol
(Guangdong Jiabo Pharmaceutical Co., Ltd, 20141229) and $0.05 \mathrm{mg} / \mathrm{kg}$ midazolam (Jiangsu Enhua Pharmaceutical Co., Ltd, Zhunzi $\mathrm{H} 10980025)$, with continuous inhalation of $2.5 \%$ sevoflurane. Anaesthesia in group C involved intravenous injection of $0.3 \mathrm{mg} / \mathrm{kg}$ etomidate (Jiangsu Enhua Pharmaceutical Co., Ltd, 20150121) and $0.6 \mathrm{mg} / \mathrm{kg}$ rocuronium (Zhejiang Xianyi Pharmaceutical Co., Ltd, Zhunzi, batch No: H20090070), also with continuous inhalation of $3.0 \%$ sevoflurane. The three groups of patients completed induction of anaesthesia. Following loss of consciousness, tracheal intubation and ventilator-assisted ventilation were carried out. During the operation, the end-tidal $\mathrm{CO}_{2}$ pressure was continuously monitored and maintained at $30-45 \mathrm{mmHg}$. The inhalation and pumping of anaesthetic drugs were stopped 5 min before the end of the operation, and tracheal intubation was removed after the extubation indications were met.

\section{Anaesthesia indicators}

Postoperative cognitive status, dizziness, nausea, vomiting and other adverse reactions were recorded, and the ratio of regulatory $\mathrm{T}$ cells (Tregs) and $\mathrm{T}$ cell lymphoids in blood were measured. Cognitive status was assessed with mini-mental state examination (MMSE) [4]. Usually, the MMSE is positively correlated with the patient's cognitive ability: the higher the MMSE score, the higher the cognitive ability of the patient. Venous blood samples $(5-\mathrm{mL})$ were collected at the beginning of anaesthesia, and they were collected $24 \mathrm{~h}$ after the operation. The proportion of Tregs $\left(\mathrm{CD} 4^{+} \mathrm{CD} 25^{+}\right)$was measured by flow cytometry, and the proportion of $\mathrm{T}$ cell subsets $\left(\mathrm{CD}^{+}\right.$and $\left.\mathrm{CD}^{+}\right)$was measured by immunofluorescence.

\section{Statistical analysis}

Data are expressed as mean \pm standard division (SD). All statistical analyses were performed with SPSS 20.0 statistical software. Measurement data such as age, weight, MMSE score, Tregs and $T$ cell subsets were compared using analysis of variance (ANOVA). Categorical data such as the ratio of male-to-female patients, and adverse reactions, were compared using a $X^{2}$ test. Values of $p<0.05$ were considered significant.

\section{RESULTS}

\section{Patients' clinical profiles}

As shown in Table 1, there were no differences in general data such as age, weight and gender amongst the groups $(p>0.05)$. 
Table 1: Biographical profile of patients

\begin{tabular}{lccc}
\hline $\begin{array}{l}\text { Group (n } \\
=126)\end{array}$ & $\begin{array}{c}\text { Mean } \\
\text { age } \\
\text { (years) }\end{array}$ & $\begin{array}{c}\text { Mean } \\
\text { weight } \\
(\mathbf{k g})\end{array}$ & $\begin{array}{c}\text { Gender } \\
\text { (Male/Female) }\end{array}$ \\
\hline Group A & $69.97 \pm$ & $59.87 \pm$ & $23 / 19$ \\
$(\mathrm{n}=42)$ & 2.08 & 2.38 & \\
Group B & $70.03 \pm$ & $60.26 \pm$ & $20 / 22$ \\
$(\mathrm{n}=42)$ & 1.97 & 2.14 & \\
Group C & $69.95 \pm$ & $60.13 \pm$ & $18 / 24$ \\
$(\mathrm{n}=42)$ & 1.99 & 2.27 & \\
$F / X^{2}$ & 0.02 & 0.32 & 1.2076 \\
$P$-value & 0.9822 & 0.7248 & 0.5467 \\
\hline
\end{tabular}

MMSE scores before and after operation

There were no differences in the scores of MMSE of the three groups before anaesthesia ( $p$ $>0.05$ ). However, the MMSE scores of the three groups $24 \mathrm{~h}$ after the operation were lower than those before the operation $(p<0.05)$.

Table 2: MMSE scores before anaesthesia, and $24 \mathrm{~h}$ after operation

\begin{tabular}{lcc}
\hline \multirow{2}{*}{$\begin{array}{l}\text { Group } \\
(\mathbf{n}=\mathbf{1 2 6})\end{array}$} & \multicolumn{2}{c}{ MMSE score } \\
\cline { 2 - 3 } & $\begin{array}{c}\text { Before } \\
\text { anaesthesia }\end{array}$ & $\begin{array}{c}\text { 24 } \boldsymbol{h} \text { after } \\
\text { operation }\end{array}$ \\
\hline $\begin{array}{l}\text { Group A }(\mathrm{n}= \\
42)\end{array}$ & $\begin{array}{c}29.13 \pm 0 \\
\text { Group B }(\mathrm{n}=\end{array}$ & $24.94 \pm 2.23$ \\
$42)$ & $28.94 \pm 0.27$ & $26.52 \pm 2.09^{*}$ \\
Group C $(\mathrm{n}=$ & $29.08 \pm 0.31$ & $23.57 \pm 2.18$ \\
$42)$ & 4.72 & 19.48 \\
$F$ & 0.0106 & $<0.001$ \\
$P$-value & \multicolumn{2}{l}{}
\end{tabular}

\section{Adverse reactions}

As depicted in Table 3, the degrees of adverse reactions in groups A, B and C were $38.10 \%$ (16/42), $33.33 \%(14 / 42)$, and $42.90 \%$ (18/42), respectively. The differences were not statistically significant $(p>0.05)$.

\section{Treg levels in blood before and after operation}

Table 4 shows that the blood levels of Tregs $\left(\mathrm{CD}^{+} \mathrm{CD} 25^{+}\right)$before anaesthesia in the three groups of patients were comparable $(p>0.05)$. The levels of $\mathrm{CD}^{+} \mathrm{CD} 25^{+}$in each group decreased after $24 \mathrm{~h}$, and were significantly higher in group B than in the other two groups $(p$ $<0.05$ ).

Table 4: $\mathrm{CD} 4^{+} \mathrm{CD} 25^{+}$scores before anaesthesia and $24 \mathrm{~h}$ after operation in the three groups

\begin{tabular}{|c|c|c|}
\hline \multirow{2}{*}{$\begin{array}{l}\text { Group } \\
(n=126)\end{array}$} & \multicolumn{2}{|c|}{$\mathrm{CD}^{+} \mathrm{CD}^{25^{+}}$(\%) } \\
\hline & $\begin{array}{c}\text { Before } \\
\text { anaesthesia }\end{array}$ & $\begin{array}{c}24 \text { hours after } \\
\text { operation }\end{array}$ \\
\hline Group A ( $n=42)$ & $3.74 \pm 0.79$ & $2.93 \pm 0.87$ \\
\hline Group B $(n=42)$ & $3.81 \pm 0.74$ & $3.46 \pm 0.71^{*}$ \\
\hline Group C $(n=42)$ & $3.78 \pm 0.81$ & $2.57 \pm 0.91$ \\
\hline$F$ & 0.09 & 12.09 \\
\hline$p$ & 0.919 & $<0.001$ \\
\hline $\begin{array}{l}{ }^{*} P<0.05, \text { group } \\
\text { h post-operation }\end{array}$ & ppared wit & Ips A and C 24 \\
\hline
\end{tabular}

The levels of $\mathrm{CD}^{+}$and $\mathrm{CD} 8^{+} \mathrm{T}$ cell subsets in the blood before anaesthesia did not differ significantly amongst the three groups of patients $(p>0.05)$. However, the levels of $\mathrm{CD}^{+}$ decreased in all the groups $24 \mathrm{~h}$ after operation, but were significantly higher in group $B$ than in the other two groups $(p<0.05)$. The level of $\mathrm{CD} 8^{+}$increased in all the groups $24 \mathrm{~h}$ after operation, but it was significantly lower in group $B$ than in the other two groups. The differences were statistically significant for both $\mathrm{CD}^{+}$and $\mathrm{CD}^{+}(p<0.05)($ Table 5).

Table 3: Incidence of adverse reactions to anaesthesia

\begin{tabular}{lccccc}
\hline \multirow{2}{*}{$\begin{array}{l}\text { Group } \\
(\mathbf{n}=126)\end{array}$} & $\begin{array}{c}\text { Vomiting } \\
\text { (cases) }\end{array}$ & $\begin{array}{c}\text { Dizziness } \\
\text { (cases) }\end{array}$ & $\begin{array}{c}\text { Chest } \\
\text { tightness } \\
\text { (cases) }\end{array}$ & $\begin{array}{c}\text { Fever } \\
\text { (cases) }\end{array}$ & $\begin{array}{c}\text { Incidence of adverse } \\
\text { reactions (\%) }\end{array}$ \\
\hline Group A $(\mathrm{n}=42)$ & 6 & 9 & 1 & 0 & 38.10 \\
Group B $(\mathrm{n}=42)$ & 3 & 8 & 2 & 1 & 33.33 \\
Group C $(\mathrm{n}=42)$ & 4 & 7 & 7 & 0 & 42.90 \\
$X^{2}$ & & & & & 0.8077 \\
$P$-value & & & & & 0.6677 \\
\hline
\end{tabular}


Table 5: $\mathrm{CD}^{+}$and $\mathrm{CD} 8^{+}$scores before anaesthesia and $24 \mathrm{~h}$ after operation

\begin{tabular}{lcccc}
\hline \multirow{2}{*}{ Group } & \multicolumn{2}{c}{ CD4 $^{+}(\%)$} & \multicolumn{2}{c}{ CD8 $^{+}$(\%) } \\
\cline { 2 - 5 } & $\begin{array}{c}\text { Before } \\
\text { anaesthesia }\end{array}$ & $\begin{array}{c}\text { 24 } \text { h after } \\
\text { operation }\end{array}$ & $\begin{array}{c}\text { Before } \\
\text { anaesthesia }\end{array}$ & $\begin{array}{c}\text { 24 } \text { h after } \\
\text { operation }\end{array}$ \\
\hline Group A $(\mathrm{n}=42)$ & $25.84 \pm 4.37$ & $17.28 \pm 3.17$ & $29.53 \pm 3.49$ & $34.94 \pm 3.51$ \\
Group B $(\mathrm{n}=42)$ & $25.76 \pm 4.56$ & $22.46 \pm 2.83^{*}$ & $29.39 \pm 3.57$ & $31.32 \pm 3.76^{*}$ \\
Group C $(\mathrm{n}=42)$ & $26.01 \pm 4.63$ & $18.42 \pm 3.05$ & $29.56 \pm 3.52$ & $35.48 \pm 3.67$ \\
$F$ & 0.03 & 34.12 & 0.03 & 16.15 \\
$p$ & 0.9671 & $<0.001$ & 0.9726 & $<0.001$ \\
\hline${ }^{*} P<0.05$, group B compared with groups A and C for each parameter 24 h post-operation
\end{tabular}

\section{DISCUSSION}

Propofol inhibits fast-onset of throat reflexes, thereby facilitating endotracheal intubation. However, propofol inhibits the circulatory and respiratory systems by reducing intracranial pressure, intraocular pressure, cerebral blood flow and oxygen consumption, all of which result in a drop in blood pressure that leads to transient dizziness, nausea, vomiting and other adverse reactions [5]. Midazolam is a good muscle relaxant, with a half-life of approximately 1.5 $2.5 \mathrm{~h}$ in normal adults, but longer half-life in elderly patients. Thus, midazolam has a lasting anaesthetic effect [5,6]. Sevoflurane is a milestone drug used as inhaled anaesthesia, and it has good analgesia and muscle-relaxant effects. Continuous inhalation of low concentrations of sevoflurane is suitable for maintaining anaesthesia during general anaesthesia, because it has less effect on airway stimuli and the cardiovascular system, but it is associated with rapid anaesthesia and recovery onset [7]. In this study, the adverse reactions rate in group B were lower than that in the other two groups, indicating that the combination of propofol, midazolam and sevoflurane improves patient comfort.

Surgical patients are often plagued by cognitive impairment after general anaesthesia. This phenomenon is more common in elderly patients as a result of their poor physical function. The present study found that the incidence of cognitive dysfunction after general anaesthesia in elderly patients over 65 years of age was as high as $25.8 \%$ [8]. In view of the fact that cognitive dysfunction after general anaesthesia is due to the neural stimulating effect of residual narcotic drugs on the patient, the occurrence of cognitive dysfunction is closely related to the type of anaesthetic drug administered [9].

The function of the human immune system gradually declines with age, and immunecompromised patients are more susceptible to infection, thereby resulting in poor prognosis. With increasing number of elderly surgical patients, reduction of the adverse stimulation of immune function during operations has become a critical issue in clinical practice. The Tregs $\left(\mathrm{CD}^{+} \mathrm{CD} 25^{+}\right)$and their related cytokines (e.g. Foxp3) are important to the immune system and can regulate the immune system as well as maintain homeostasis of immune cell populations [10]. In the cytoplasm, Foxp3 is a specific transcription factor which transcribes the mRNA of a specific protein that promotes immune regulation of $\mathrm{CD}^{+} \mathrm{CD} 25^{+}$Tregs [11]. Studies have previously shown the potential role of CD4+CD25 $5^{+}$Tregs in regulating other immune cells and reducing the incidence of autoimmune diseases [12]. The present study shows that the combination of propofol, midazolam and sevoflurane had minimal impact on the level of Tregs $\left(C D 4^{+} C D 25^{+}\right)$in peripheral blood, and was beneficial in maintaining homeostasis in immune cell population. $T$ cell subsets in the blood serve as criterion for assessing immune function. The $T$ cell subsets comprise two subgroups: $\mathrm{CD}^{+} \mathrm{T}$ cells and $C D 8^{+} T$ cells using specific monoclonal antibodies [13]. The $\mathrm{CD4} 4^{+} \mathrm{T}$ cells are also called helper $T$ cells. Under the regulation of Tregs, they are involved in immune surveillance of cancer cells. It has been confirmed that the ratio of $\mathrm{CD}^{+}$to $\mathrm{CD}^{+} \mathrm{T}$ cells in the blood is significantly reduced in malignant tumour patients whose immunity is in a suppressed state [14]. The present study shows that the combination of propofol, midazolam and sevoflurane anaesthesia in patients has minimal impact on the levels of $\mathrm{CD}^{+}$and $\mathrm{CD}^{+} \mathrm{T}$ cell subsets in peripheral blood, and is beneficial for maintaining the patient's own immune system.

\section{Limitations of the study}

Few participants were included in this research and this research was a single centre based study. Whether the propofol, midazolam and sevoflurane have a long-term effect on patients still needs a further research.

\section{CONCLUSION}

The anaesthetic combination of propofol, midazolam and sevoflurane has rapid anaesthetic onset and recovery. It improves 
patient's comfort and decreases the negative impact of anaesthesia on immune system function. Furthermore, it improves recovery in elderly patients.

\section{DECLARATIONS}

\section{Conflict of Interest}

No conflict of interest associated with this work.

\section{Contribution of Authors}

This work was done by the authors named in this manuscript, and the authors accept all liabilities resulting from claims which relate to this manuscript and its contents. The study was conceived and designed by $\mathrm{Yao} \mathrm{Yu}$, while $\mathrm{Ye}$ Hua, Wang Jin-Zhuo, Wu Zhen-Zhong collected and analysed the data. Wang Feng-Juan wrote the manuscript. All authors read and approved the manuscript prior to publication.

\section{REFERENCES}

1. Wang MF, Pu JF, Ren JG, Huang X, Pan SL. Effects of different doses of dexmedetomidine combined with remifentanil propofol controlled hypotension on stress response and immune function in patients undergoing nasal endoscopic surgery. Hebei Med J 2016; 32(11): 1094-1096.

2. World Health Organization. Declaration of Helsinki. Br Med J 1996; 313(7070): 1448-1449.

3. Arevalo-Rodriguez I, Smailagic $N$, Roque I, Figuls $M$, Ciapponi A, Sanchez-Perez E, Giannakou A, Pedraza OL, Bonfill Cosp $X$, Cullum S. Mini-Mental State Examination (MMSE) for the detection of Alzheimer's disease and other dementias in people with mild cognitive impairment (MCl). Cochrane Database Syst Rev 2015; 3(3): 010783.
4. Yu H, Wang DF, Wang XZ, Liu X. Effects of propofol and midazolam on stress indicators in patients after craniocerebral injury operation. Chin $J$ Integr Tradit Western Med Intensiv Crit Care 2016; 23(3): 299-302.

5. Conway A, Rolley J, Sutherland JR. Midazolam for sedation before procedures. Cochrane Database Syst Rev 2016; 5(5): 009491.

6. Luo Y, Yao SL, Yang BX, Li EY, Lan ZX, Zhu SM, Gu $M N, Y u B W$. A multicenter registry to estimate the behavior of Chinese anesthesiologists practicing general anesthesia with sevoflurane. J Clin Anesthesiol 2016; 32(1): 6-9.

7. Benno B. Postoperative cognitive dysfunction in the elderly. Lancet 1998; 351(9119): 1888-1889.

8. Chi YL, Li ZS, Lin CS, Wang Q, Zhou YK. Evaluation of the postoperative cognitive dysfunction in elderly patients with general anesthesia. Eur Rev Med Pharm Sci 2017; 21(6):1346.

9. Gao $P, L u Y S$, Wu L, Luan $Y$, Ding MM, Zhang $X D$, Guan $X Q$. Effect of Cinobufotalin on the Thelper cells 17 and regulatory $T$ cells and the related factors of patients with lung cancer. Chin J Clin Pharm 2016; 32(10): 871-873.

10. Zhang YD, Wang $Q Q$. Changes of levels of CD4+CD25+Foxp3+regulatory $T$ cells in HDCP peripheral blood and its significance. Chin J Immunol 2015; 9(9):1253-1256.

11. Grygorowicz MA, Borycka IS, Nowak E, PaszkiewiczKozik E, Rymkiewicz G, Błachnio K, Biernacka M, Bujko $M$, Walewski J, Markowicz S. Lenalidomide potentiates CD4+CD25+Treg-related suppression of lymphoma $B$ cell proliferation. Clin Exp Med 2017; 17(2): 193-207.

12. Wang Y, Wang LL, Han S, Bai YP. Progress in the Relationship between $C D 4 \sim+T$ Lymphocyte Subsets and Psoriasis. J Cell Mol Immunol 2016; 32(6): 834-836.

13. Schlober HA, Drebber U, Kloth M, Thelen M, Rothschild SI, Haase S, Garcia-Marquez M, Wennhold K, Berlth F, Urbanski $A$, et al. Immune checkpoints programmed death 1 ligand 1 and cytotoxic $T$ lymphocyte associated molecule 4 in gastric adenocarcinoma. Oncoimmunology 2015; 5(5): 1100789. 